\title{
Tribute to an 'obnoxious' ecocatalytical demotechnician: Jack Vallentyne on population
}

\author{
Stuart H. Hurlbert* \\ Department of Biology and Center for Inland Waters, San Diego State University, San Diego, California 92182, USA
}

\begin{abstract}
The late John R. Vallentyne was a limnologist and one of Canada's most influential scientists in the latter half of the last century. While his work in institution-building and in improving water quality in North American lakes is widely known, his creative, if infrequent, writings on human overpopulation and its environmental consequences are less so. This tribute analyzes these, starting with his concept of demotechnic growth, relating his thoughts to those of David Suzuki and Garrett Hardin, 2 admirers who encouraged him to write his cry-from-the-heart book, Tragedy in Mouse Utopia, which was published shortly before his death. His ideas are related to current population issues such as immigration and the estimation of environmentally sustainable population levels. An attempt is made to explain his relative silence on Canada's population and immigration policies. He has left some of the heavy-lifting to his colleagues and the next generation.
\end{abstract}

KEY WORDS: John R. Vallentyne · Population growth · Demotechnic growth · Tragedy in Mouse Utopia · Garrett Hardin · David Suzuki · Johnny Biosphere · Censorship

Here is one of the basic puzzles of our time. Most of us can look out the window ${ }^{1}$ and realistically claim to be living under the best environmental circumstances that have ever pertained; yet, at the same time, persons of intelligence and consequence are increasingly rising in our midst, prophesying doom. Are these judgments mutually exclusive? Is it conceivable that both might be right?

$$
\text { J. R. Vallentyne (1975, p. G1) }
$$

Can an ecologist challenge the economic doctrine of global economic growth without limit and win?

J. R. Vallentyne (2006, p. 3)

\section{INTRODUCTION}

John R. 'Jack' Vallentyne was one of Canada's most influential scientists during the latter part of the last century. After teaching stints at Queen's University

\footnotetext{
IIt was May 15, 1974, and Jack would have been looking out the window of a meeting room in the famous Fort Garry Hotel at the spring greenery of Winnipeg (detective work courtesy of Kerry Macdonald, Regional Librarian, Fisheries \& Oceans Canada).
}

(Kingston, Ontario) and Cornell University (Ithaca, New York), he returned to Canada in 1966 to develop a research program on eutrophication at the Freshwater Institute in Winnipeg. Hiring top notch scientists from around the world for his team, within a few years he made this institute one of the world's most outstanding centers for limnological research. He played a leading role in getting phosphates removed from detergents in North America, thus slowing eutrophication on a continental scale. He also played a major role in infusing an ecosystem approach into the US-Canadian 1978 Great Lakes Water Quality Agreement. He was, in general, an extremely effective communicator of scientific and environmental information to bureaucrats, politicians, scientists and children alike. During the latter part of his career he traveled the world and classrooms as 'Johnny Biosphere', with a $30 \mathrm{~cm}$ globe of the world on his back that flashed lightning and emitted the sounds of falling rain, thunder and a calling loon.

An early demystification of my title may set minds at ease. As I recount later, Jack once argued (Vallen- 
tyne 1972a) that when attempts were made to take population issues off the table on political or ideological grounds, we should be 'obnoxious' in our insistence they be put back on the table.

As for 'ecocatalytical,' Jack suggested 'ecocatalyst' as an appropriate descriptor for the effective environmental activist. In his own words (Vallentyne 1994, p 533):

A catalyst is a chemical that hastens the rate of a reaction by lowering the activation energy required for the reaction to proceed. ... Catalysts participate in the reaction and are regenerated in the process - ready to initiate another transformation. In an analogous manner, 'ecocatalysts' are persons who hasten the rates of social transformations already destined to proceed.

Jack was an ecocatalyst par excellence. Such can have an effect even when scarce or in low concentrations.

Jack died in 2007. The man and his accomplishments were soon the subject of several tributes (Schindler 2007, Planas 2008, Blanchfield et al. 2009). Seventeen additional essays on Jack and his influence, as well as his curriculum vitae and publication list, have been published in a recent issue of Aquatic Ecosystem Health and Management (Munawar 2011). Among these is a brief account of my own 'serendipitous intersections' with Jack, which began when, as a graduate student, I had an office next to his at Cornell (Hurlbert 2011a).

So why this additional tribute to Jack?

Underlying all of Jack's concerns for environmental quality and our environmental future, was Jack's understanding of the threat of overpopulation. His writings on the topic were sparse but prescient. Only in a book, Tragedy in Mouse Utopia (Vallentyne 2006), published shortly before his death, did this reserved man unleash his inner censor and give us the full force of his thoughts. It is thus understandable that his contributions in this area have been underappreciated, going essentially unmentioned, for example, in the 20 memorial essays and obituaries mentioned above.

In the course of preparing my own essay for the memorial issue of Aquatic Ecosystem Health and Management, I re-read all of Jack's papers dealing with population issues and felt the best tribute to Jack would in fact be an exegesis of them and relating of them to current issues of population and immigration, including the ideas of 2 persons, David Suzuki and Garrett Hardin, that Jack acknowledged as having urged him to write Tragedy in Mouse Utopia. The resulting analysis exceeded in length what could reasonably be included in the memorial issue of Aquatic Ecosystem Health and Management, and so it is presented here. By a stroke of good luck, this has allowed it to be published here as a companion piece to an important but long-in-limbo manuscript co-authored by $\mathrm{Jack}^{\underline{2}}$ (Mata et al. 2012, this issue), along with an extensive commentary by William Ryerson, president of both the Population Institute (Washington, DC) and the Population Media Center (Shelburne, VT) (Ryerson 2012, this issue).

\section{DEMOTECHNICS, A MAJOR BUT NEGLECTED CONTRIBUTION}

Once he was no longer troubleshooting amino acid analyzers at Cornell for his biogeochemical investigations of lake sediments, had his star-studded team of scientists at work on Canadian lakes, and had come out victorious from mano a mano combat with detergent manufacturers, Jack had more time for philosophy, new biopolitical initiatives and further environmental activism and education. One important fruit of his post-1971 career was the concept of demotechnic growth. This refers to the joint action of increasing numbers of humans and increasing per capita rates of resource consumption and waste production.

That fruit remained to some extent hidden in the foliage of his own modesty, however. Perhaps this essay and its 2 companions will function as defoliant. It is more than passingly curious that a man would hide his demotechnic light under a bushel who had no qualms about walking around as Johnny Biosphere with a flashing globe of the world on his back that delighted children but occasionally embarrassed his family (according to son Peter), frightened waiters, motorists and pedestrians, and would have put any post-9/11 airport security system into Code Red.

Jack's first publications on demotechnic growth (under the later abandoned label of demophoric growth) were a book chapter (Vallentyne 1972a) presenting his keynote address to the First International Conference on Environmental Future, and 2 notes (Vallentyne 1972b, Vallentyne \& Tracy 1972) that merely explained the coinage of the terms 'demophora' and 'demophoric'. In the keynote address, Jack assembled and discussed some data sets on population, water supplies, water use and pollutant

\footnotetext{
2Originally prepared for and presented at the International Conference on Population and Development (ICPD) Cairo, Egypt, 5-13 September, 1994. [Previously circulated by the Earth Council, San Jose, Costa Rica]
} 
discharges. He again presented the concept briefly and in qualitative terms when he gave a talk titled 'Responsible statehood: the need for a population policy' (Vallentyne 1975) at a forum sponsored by the Manitoba Environmental Council with the aim of helping the Canadian government ascertain the Canadian public's attitude toward population issues.

It was not until his presidential address to the International Society of Limnology in Copenhagen in August 1977 (Vallentyne 1978), however, that the concept really gained some traction. He built on the 'energy slave' concept of Bryson \& Ross (1972) and found a way to quantify a demotechnic index (Dindex) in a way useful for international analyses and comparisons. Reliable, annual country-by-country data on resource consumption and waste production were not and are not generally available. The data on technological energy consumption (fossil fuels, hydroelectric, nuclear) that are compiled in the Statistical Yearbooks of the United Nations are the sole exception.

To put things into 'metabolic' terms he defined in his 1978 paper one D-unit as the 'physiological energy consumption' of a person with a reasonable diet representing $840000 \mathrm{kcal} \mathrm{yr}^{-1}\left(=2300 \mathrm{kcal} \mathrm{d}^{-1}\right)$. Average per capita 'technological energy consumption' for a given country could then be quantified by a Dindex calculated as the total technological energy consumption ( $T$, in kcal) of the country divided by $840000 \mathrm{kcal}$. Using the UN data for 1973 he obtained D-index values ranging from 97 for the USA and 91 for Canada to $<2$ for most of Africa (Vallentyne 1978). In the USA each of us in 1973 had, on average, the environmental impact of 97 'energy slaves' - plus our own food consumption - to answer for. (Jack mistakenly used $829000 \mathrm{kcal}$ as one D-unit in his calculations for the paper mentioned, but its general conclusions were not thereby affected.)

The genius of this approach is that per capita energy consumption is roughly correlated with both per capita consumption of resources generally and with per capita production of wastes or pollution. As such, it is as good a general measure of per capita impact on the environment as we are ever likely to have. It allowed the environmental impacts of a country to be viewed not as a function of just its population size $(P)$ but as a function of its 'human population equivalent' or, more felicitously, 'consumptionadjusted population' (Mata et al. 2012), i.e. as:

$$
C=P(1+\mathrm{D} \text {-index })
$$

Thus, in 1973, for the USA (D-index $=95.7$ ) and China (D-index $=4.94), P$ was 210 and 814 million, respectively, while $C$ was 20307 million for the USA and only 4835 million for China. That is, the global environmental impact of the US population was about 4.2 times greater than the global environmental impact of China's population (numbers from Vallentyne 1978, corrected by setting one D-unit equal to $840000 \mathrm{kcal})$.

Further discussions and updating of these numbers are given in Mata et al. (2012), Vallentyne (1994, 2006), Schindler \& Vallentyne (2008), among others. Vallentyne \& Hamilton (1987) noted that for the $754000 \mathrm{~km}^{2}$ St. Lawrence Great Lakes Basin ecosystem, C increased >5000-fold between 1800 and 1986 . Of particular interest is Table 12.1 in Vallentyne (2006, p. 89). This shows that, for the world as a whole between 1950 and 2000, $P$ increased by $141 \%$, the D-index by $98 \%$ and $C$ by $375 \%$.

The first practical application of the D-index was made when, at the end of his second term as president of the International Association of Limnology (SIL), Jack pushed through the General Assembly at the Kyoto SIL meeting, 'a $25 \%$ reduction of annual dues for individual members from developing countries for the next three-year period... [where] a new definition of a developing country was used: a country with a demophoric index less than one-half of the global average' (Vallentyne 1980). Later he put forward a more complex but more logical algorithm based on the Dindex that could be used for calculating membership dues (both national and individual) for international organizations generally (Vallentyne 1982).

Jack's concept of demotechnic growth and his way of quantifying it have not yet received the attention - or credit - they merit. Partly this was simply because he was not aggressive in doing analyses of and with it in standard journal literature. Consequently, even his fellow limnologists and ecosystem ecologists have done little to spread the word so far. Wetzel (2001) discusses the concept in his first chapter, but no other limnology textbook I know of mentions demotechnics. The excellent second edition of The Algal Bowl (Schindler \& Vallentyne 2008) brings the concept into discussion at various points but does not emphasize it. Schindler (2000), however, earlier made 'demotechnic dilemmas' a central focus of an essay that deserves wider attention.

A second major reason for neglect of $C=P(1+\mathrm{D}$-index) was the nearly simultaneous formalization by Ehrlich \& Holdren (1972) of an idea in a footnote by Commoner (1971, p. 317) into 'their' now famous ' $I=$ $P A T$ ' equation, or 'IPAT,' where the impact (I) of a human population is the product of its size $(P)$, its 'afflu-

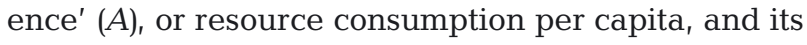


'technology' $(T)$ or the 'relative environmental impact of the technology that provides the affluence.' The first version of IPAT was simply $I=P F$, where $F$ measured 'per capita impact' (Ehrlich \& Holdren 1971).

IPAT also was a brilliant concept and was aggressively promoted by Ehrlich and Holdren and then the scientific and environmental communities generally. Part of its appeal is the word 'affluence' which tends to connote 'overconsumption' and thus appeals to those who wish, for ideological or political reasons, to deemphasize the role of population growth. 'Material standard of living' might be a more neutral label for the ' $A$ ' factor. Separating out the 'technology' factor is conceptually useful in making clear that ' $T$ ' will be very different according, for example, to whether a million units of energy are obtained via burning high-sulfur coal or via capture of wind or solar power.

The IPAT approach has been implemented quantitatively for particular resources, products and technologies, starting with Commoner $(1971,1972)$ and Ehrlich \& Holdren (1972) and reviewed, critiqued, modified and extended by many others (e.g. Dietz \& Rosa 1994, Chertow 2000, Wagonner \& Ausubel 2002, York et al. 2003). It is often also used merely as a general concept or mantra. There is no straightforward way in which the ' $A T$ ' part of the equation can be quantified for the collectivity of all the ways in which a population is impacting the environment. Both Jack's D-index and IPAT were also foundations for the concept and methodologies of 'ecological footprint' analysis (Rees 1992, Rees \& Wackernagel 1994, Wackernagel \& Rees 1996, Wackernagel et al. 1999).

Mata et al. (2012) were candid about the obvious limitations of the D-index. Jack referred to it as a 'rough-and-ready index of affluence' only, though in a footnote explaining why he never switched to IPAT he said he preferred 'an expression that put population and technology up front and permitted them to be related quantitatively' (Vallentyne 2006, p. 89, p. 173). There Jack was referring, however, not to the ' $T$ ' in IPAT but rather back to his distinction between 'physiological energy consumption' and 'technological energy consumption' $(T)$.

\section{PEDAGOGIC VALUE AND IMPLICATIONS OF DEMOTECHNICS}

For the general purpose of communicating in a concrete manner the 'big picture' on populationenvironment issues to students, scientists, decisionmakers, religious leaders, UN delegates, or the general public, $C=P(1+\mathrm{D}$-index $)$ seems superior to
IPAT. We all should commit to getting the word out and making up for almost 4 decades' worth of lost time.

An explanation of demotechnic growth is a powerful, eye-opening way to introduce the state of the planet and human population early in any introductory course on ecology or the environment. In my limnology course, students were introduced to the concept via Mata et al. (2012) in the first week. They were challenged to use the 1990 data on population and energy consumption presented there to calculate how large the world population could be if (1) everyone were to have the same material standard of living as reflected by the D-index for the USA (91.3) and (2) the total technological energy available per year was that actually consumed globally in 1990 .

The result of that calculation is 1.13 billion people. If we use the D-index for the winter-plagued Canadians (118.1), a supportable global population is only 0.71 billion. The planet at present ( 7 December 2011) has 7.14 billion people.

Similar calculations were the basis for Jack's conclusion that, 'At an average 1973 U.S.A. lifestyle the sustainable ... human population globally is probably of the order of 1-2 billion at most' (Vallentyne 1994). This opinion is in line with estimates by other scientists based on other sets of assumptions, that the world could sustain a population of 1 to 3 billion at a reasonable average standard of living (Ehrlich et al. 1993, Daily et al. 1994, Pimentel et al. 1994, 1999, 2010, Pimentel \& Pimentel 1996, Wackernagel \& Rees 1996, Ferguson 1998, 2001, Smail 2002, 2003, Desvaux 2007, Mann 2009).

Pimentel et al. (2010) estimate that a sustainable United States population would be 200 million persons. That calls to mind an early paper by Holdren (1973) wherein he argues that '[the] 210 million [here] now is too many and [a projected] 280 million in 2040 is likely to be much too many' (p. 41). The population of the United States has now reached 309 million and continues to grow at about $1.0 \% \mathrm{yr}^{-1}$, but Holdren no longer seems perturbed. His February 2007 presidential address to the annual meeting of the American Association for Advancement of Science was titled 'Science and technology for sustainable well-being' (Holdren 2008). Though about 9300 words long (excluding figures and footnotes), only 1 sentence ( 24 words) was on population, and that simply noted that 'continued population growth' exacerbated all the other problems, environmental and otherwise, he was discussing. Helping develop support for population stabilization and then population reduction, national and global, was not one of the 
tasks he was suggesting for the scientific community. And this was before he was put on a short leash and became President Obama's chief science advisor. In that capacity his major addresses and reports on science and sustainability (Holdren 2011, PCAST 2011) have been equally silent on population issues, as discussed elsewhere (Hurlbert 2011f). Johnny Biosphere, as an 'obnoxious' old lion who kept his teeth, would be appalled.

Schindler (2000, p. 122) guessed that 'with its current demotechnic index,' an environmentally and economically sustainable population for Canada is 'probably less than ten million people.' The current (July 2011) population of Canada is 34.5 million.

The prospects for a near-term and large voluntary lowering of the average $D$-indices of Canadians and Americans are not great, desirable as this is. In both countries there are large, low-income segments of those populations that are hardly practitioners of some sort of immoral overconsumption, even if other segments might be so regarded. Hanauer (1998, p. 2) importantly has noted:

In many environmental and population circles, the traditional thinking dictates that the problem in developing countries is overpopulation, while in the developed world the bulk of the problem is overconsumption ... In the developed world, per capita consumption levels are all within the same order of magnitude ... [M]ost third world consumption levels are between 0.5 and 5 percent of ours. This vast difference is not because these people recycle, use little plastic and don't drive a turbocharged car - it is because they have no car, no central heat, and no refrigerator and maybe no house at all! It is this lack of the most basic items, items which most of us believe every human should be able to have, which make up most of the consumption difference between the haves and the have nots. ... Reasonable levels of consumption are not morally wrong, in fact most of us believe that they are desirable. We need ... population stabilization or reduction for all [countries]. Population levels are critical to the dream and are too often overlooked.

Smail (1997, p. 233) makes the same point in saying:

[I]t should not be surprising to anyone that the lessdeveloped world's typical response to suggestions that they significantly curtail their 'rampant' population growth is an equally emphatic call for developed nations to greatly reduce their 'profligate' consumption levels, or population, or both!

Reflecting a somewhat contrary view, Mata et al. (2012, p. 20) conclude by saying that 'a reduction of population growth in developing countries and a reduction of consumption in developed countries are both needed to achieve sustainability.' This is the 'traditional thinking' that Hanauer (1998) was critiquing. Hanauer and Smail have it right. The developed countries benefit both themselves and the world greatly when their population growth rates drop to zero or become negative. Reducing the population of the USA by 1 person reduces environmental impacts (= $1+\mathrm{D}$-index) by the same amount as would reducing the population of Bangladesh by 41 persons, according to the 1990 D-index values provided by Mata et al. (2012). And 'deleting' 1 Canadian is worth 53 Bangladeshis - so long as it's not just another hockey player moving to the United States. Or we can look at the lifetime environmental impacts of a newborn American, Canadian, or Bangladeshi, taking into account that their life expectancies are 78, 81 and $60 \mathrm{yr}$, respectively (CIA 2010). In that case, the average American baby will do damage equivalent to that of 53 Bangladeshis and the average Canadian baby will do damage equivalent to that of 71 Bangladeshis.

\section{THE OBNOXIOUS ECOCATALYST AND BEARDER OF CENSORS}

A strong focus on demotechnic growth (or, equally, the IPAT or ecological footprint formulations) was not only appropriate from a strictly scientific point of view, but was also good strategy for addressing the politics of population-environment problems on the international stage. Western scientists were making it clear that these problems were not just a function of the 'high birth rates and teeming millions in the third world', but were equally a function of high per capita resource consumption and waste production rates in a rather small number of wealthy nations. This set the stage for potentially more harmonious discussions in and effective actions by the UN and other international bodies.

Following Jack's keynote speech at the First International Conference on Environmental Future in 1972 there was a lively discussion. A transcript of this, with supplementary comments, is included in the published version of the speech (Vallentyne 1972a, p. 200-211). Discussants included, among others: Nicholas Polunin (editor of Biological Conservation, chairman of the conference and editor of the proceedings), Gordon Butler (National Research Council of Canada), Lynton Caldwell (Indiana University) and Stanley Johnson (International Planned Parenthood Foundation). Some of the pungent remarks relating to censorship still have great relevance and suggest Jack's dander was up.

At the beginning of Jack's paper, a footnote by editor Polunin states: 'The author has requested this footnote indication that the preamble to his paper 
which he considered essential has been deleted editorially, though an attempt has been made to preserve its spirit in the introductory paragraphs.' From those introductory paragraphs, one can infer that the preamble had something to do with 'a porcine analogue to the human population.' Jack was evidently not minding his manners!

In the discussion, Butler really got the ball rolling by stating:

I share Dr Vallentyne's view about the necessity of having an objective discussion of this [population] problem, but it is not practicable to do it at the United Nations Conference in Stockholm [in 1972], and I'll tell you why ... there are some developing and developed countries which have as one of the elements of their national policy - a very strong element - that they will not admit that they have a population problem; they want more population not less ... consequently I think one of the most useful things this present Conference can do is to bring it right out into the open.

Then Johnson chimed in to note that this:

opposition ... includes the governments of Latin America who either suspect the hand of Yankee imperialism in UN efforts or want to fill up their own countries - and it also includes Catholic governments elsewhere. Particularly involved are the old Catholic countries of Europe: France, Belgium, Italy, Ireland. The opposition also includes African countries that have similar suspicions of the motives of the [UN] Fund for Population Activities and of family planning programmes in general ... I think there is a way out of the political dilemma - a way which Dr Vallentyne's clever coining of words suggests, indeed helps to make clear - and it is this: if you put forward the population problem and emphasize that it is in fact a demophoric problem, a combination in different measures of peoples and wealth, then point the finger at the industrial societies because of their impact, you should have a chance of persuading even the Brazilians!

Polunin also offered some encouraging words:

Mr Johnson mentioned Mr Strong's [then head of the UN Environment Programme] openness of mind on this matter of population versus environment to which I, too, can testify. Indeed he expressed keenness to me that we should debate it and some other matters quite frankly and let his people have the results of our deliberations in good time for the drafting of the papers for Stockholm. ...So you see our hopes of contributing indirectly but usefully to the Stockholm Conference ought to materialize, especially as several of us here are acting as consultants to it...

Then there was the following exchange between Jack and Polunin:

Vallentyne: Just as a point of verification, my reference to the United Nations in the preliminary notes which I sent you some months ago is not in the final paper. I was informed in Canada that the Brazilians flatly refuse to discuss population, and that it could not be brought up at Stockholm in 1972. So I took it out.
Polunin: You should jolly well put it back in.

Vallentyne: Put it back in?

Polunin: Yes, please.

Vallentyne: I'll be glad to do so if it will not inhibit the development of global discussion.

Polunin: I remember those remarks very well and I thought, well, here is another who really understands the true situation and has the courage to speak out about it.

Jack's 'preliminary notes' do not survive so we cannot ascertain to what extent they were incorporated into his published article. There is evidence, from Butler, that at least Jack's strongest opinions were not incorporated, however. Butler quoted the following from the last page of his copy of Jack's 'preliminary notes':

Most prominent among the myths that we live by is the notion that we can maintain a collective control over death (laws and social customs pertaining to health and survival) and yet not over birth (which is what we can and must control). The current laissez-faire attitude to human population is the basic cause of environmental problems. If the UN Conference on the Human Environment, to be held in Stockholm in 1972, faces this issue squarely, there will be hope for the future. If it does not, then those individuals, agencies and governments that feel strongly on the matter, should become obnoxious [emphasis supplied] in bringing the issue into uninhibited discussion.

No such words are found in Vallentyne (1972a). Did Jack cleverly arrange this discussion as a good cop-bad cop routine that got a tough message out in print while allowing him a certain amount of deniability? One likes to think so!

Finally, Caldwell made an observation especially relevant to current US population politics:

The President of Mexico [then Luis Echeverría Alvarez] said not long ago that they [Mexico] need more people to develop their resources: well, I think he couldn't have been more wrong, but that is the way he put it, the way he was thinking about it.

Caldwell was right as evidenced by the fact that since 1972 many millions of Mexicans have moved to the USA. As of 2008 there were about 11410000 persons born in Mexico currently residing in the USA (USCB 2009). About 6650000 of these were here illegally (Hoefer et al. 2010). Moreover, $46 \%$ of Mexican adults recently polled in Mexico say they would move to the USA if they could, and $21 \%$ say they would come illegally if necessary (Suro 2005). Such mass flows have been and are being favored and facilitated by powerful corporate interests and governmental corruption in the USA and Mexico. For some decades they also have been aided by very unVallentynian, heavy-handed censorship of 'obnox- 
ious' opinion within the environmental, academic and scientific communities (e.g. Beck \& Kolankiewicz 2000, Hurlbert 2000, 2011b,c,d,e,f, Meyerson 2004, Walker 2011) by those ideologically opposed to open discussion of USA overpopulation.

Across the western world, environmental scientists in general have been timid about supporting those few and mostly small organizations (e.g. Californians for Population Stabilization, Floridians for a Sustainable Population, Vermonters for a Sustainable Population, Minnesotans for Sustainability, NumbersUSA, Federation for American Immigration Reform, Population Institute of Canada, Immigration Watch Canada, Sierrans for U.S. Population Stabilization, Sustainable Population Australia, Optimum Population Trust, Negative Population Growth, Carrying Capacity Network) who believe that one should focus strongly on reducing demotechnic growth in one's own country before telling other countries what to do.

In his later publications, Jack pushed back with ever greater vehemence against individuals and institutions advocating increased population and demotechnic growth. In Vallentyne (1994, p. 538), for example, he says:

If businessmen and politicians could have their way they would, I suspect, opt for periods of constant rapid growth punctuated by catastrophes-assuming, of course, that they would be among the survivors. The belief system that supports the myth of constant growth persists in large part because the dead cannot speak. ... Projections of world population have suggested to some the possibility of a human population in excess of 10 billion by 2025 . If these numbers are actually realized, the mean quality of life will almost certainly be lower than at present ... Politicians do not want to become involved in the growth issue because it would spell political disaster for them in their constituencies.

In his last sole-authored work, Tragedy in Mouse Utopia: An Ecological Commentary on Human Utopia (Vallentyne 2006, p 50, 53, 90, 92, 107, 141), Jack pulled out all the stops, bearding any remnant of an inner censor. Very partially, and not to deny the many positive thoughts and suggestions he offers:

The whole history of technological civilization has been to disengage from nature, to worship money, to covet land as a commodity, to ravage forests, to drain wetlands, and to send wastes downwind and downstream for as long as you can get away with it ... It is a dangerous fantasy to see yourself as separate from nature. It is ecological madness, pure and simple ... The three primary evils of technological civilization based on demotechnic reasoning are: money, the clock, and forms of advertising and propaganda based on deception ... People everywhere have tried to reduce the human impacts of the growth of technology and population without fundamentally changing their ways ...
What made these [major environmental] tragedies particularly disgusting was that most people were unaware of what was going on in their own back yards ... Growth is still subsidized on the false belief that further growth will bring wealth and happiness to most people. In fact, the reverse is more likely to be true. Further growth will only increase the power and wealth of those who make money from the bonanza ... [M]ost large organizations that control human behavior have misconstrued, ignored or bypassed the most fundamental discoveries that have been made in biology, ecology, and evolution ... Most religions encourage war by providing spiritual support for the fighters and consolation for the bereaved. Religions that encourage belief in a personal after-life invite ecological disaster by separating people from their surroundings.

\section{UN CRI DE COEUR POUR LA BIOSPHÈRE}

The last time I communicated with Jack was in February 2007, shortly after Tragedy in Mouse Utopia had been published. I wrote to Jack to tell him how good I thought the book was. His response was to ask me if I could help get the book reviewed by some scientific journals. It seemed an odd request, because he did not tell me that he was seriously ill.

As evidenced by the quotes in an earlier section, Mouse Utopia is Jack's last plea, a true cry from the heart, and the shy guy of Tucumán (Hurlbert 2011a) is nowhere in evidence. He opens the book by quoting Polonius's advice to his son: 'This above all — to thine own self be true; and it must follow as the night the day, thou canst not then be false to any man. [Hamlet, Act I, Scene 3]' Jack was announcing that he was about to release his 'inner Doberman' and exhorting the reader to do the same. By the end of his preface he is urging us:

This book is about the life or death of a global technological civilization. Read it! Read it! And read it again! Then, act in accordance with your new understanding and perceptions.

Jack's emotional investment in the message of the book was also evident in the exuberant title that in 2001 he was planning to use for it: The Ego-System and the Ecosystem: Ecological and Evolutionary Paths to a Cosmic Civilization (J. R. Vallentyne, email to G. Brunskill, 9 April 2001). Fortunately, some wise friend or editor intervened!

Mouse Utopia was Jack's facetious label and metaphor for mankind's present dystopia. It refers to a $9 \mathrm{~m}^{2}$ indoor enclosure into which J. B. Calhoun (1973) introduced 4 pairs of mice in 1968. The population grew, food, water and nest boxes were always supplied in excess of need, and bedding materials were changed every 6 to $8 \mathrm{wk}$. Disease and predators 
were absent. The population peaked at 2200 mice around Day 560. Long before that, social strife and physiological dysfunction were evident and survival of newborn mice was poor. The population then declined slowly to 1000 mice by about Day 1100, and rapidly to zero by Day 1644. All in the face of unlimited material resources. This is what mankind may do to itself, Jack was telling us, if it ever gets cold fusion to work or finds some other source of unlimited energy. Or perhaps even if it doesn't get these.

Jack characterized Mouse Utopia as 'a critique of human societies for their failure to incorporate the findings of biology, ecology and evolution into their operations' (Vallentyne 2006, p. 163). It is a deeply philosophical book, one very different from any other on the connections of population, technology and the biosphere. It is not linearly analytical and abounds with references to history, literary works, human psychology and morality. Sigmund Freud, Emmanuel Kant, Sun Tzu, Norman Cousins, Teilhard du Chardin, H. G. Wells, Kahlil Gibran, Michael Moore, Erik Erikson and Ivan Illich are all there, with Rachel Carson, Paul Ehrlich, G. Evelyn Hutchinson, Gaylord Nelson, Lester Brown and, of course, Johnny Biosphere. The rich mixture is not easily digested on a first read, but one is rewarded by following Jack's advice to 'read it again!' And again. Purchase a few extra copies as gifts for open-minded friends and relatives concerned about the planet.

\section{JACK AND DAVID SUZUKI}

Jack mentioned David Suzuki, perhaps Canada's best-known environmentalist and environmental educator, as one of the persons who encouraged him to write Mouse Utopia (Vallentyne 2006, p. v). There seems to have been a mutual admiration society here.

Jack suggested that, 'Readers interested in developing an understanding of the need for this book can best consult the many books and television tapes prepared for general audiences by the talented scientist, author and television personality, David Suzuki.' (Vallentyne 2006, p. 163).

For his part Suzuki recalls, 'I was a big admirer of his efforts to popularize ecology. He used to go to meetings and into schools with a back pack atop which was a globe and he called himself Johnny Biosphere. It was my first exposure to the ecological message from an ecologist and I encouraged him to write his autobiography' (D. Suzuki, email to S.H.H., 18 February 2010).
In that same message and in response to my query, Suzuki says, 'I never talked to Jack about population, and I have no idea what his position was on the issue.' So Suzuki was not specifically urging that demotechnics be the focus of a book by Jack. And from the available public evidence, Jack likewise had no reason to think that Canada's overpopulation was a major concern for Suzuki. For all the good works of Suzuki over many decades, one finds nothing concerning overpopulation on the website of the David Suzuki Foundation or in its programs (www.davidsuzuki.org/). His book, Good News for a Change: Hope for a Troubled Planet (Suzuki \& Dressel 2002), likewise avoids the issue, aside from a brief reference (p. 325-326) to the need for 'raising the status of females,' in a section that begins, 'There is one environmental problem most people can agree on; there are getting to be too many of us.' Note the verb tense.

One senses that on issues of population Suzuki has wished to keep his own counsel, perhaps for strategic reasons. Beware, however, the mild-mannered interviewer! In December 2008, Hans Tammemagi, adjunct professor of Environmental Studies at the University of Victoria, British Columbia, got Suzuki to open up on population a bit. As Tammemagi (2008) recounts in his blog:

Recently I had the privilege of interviewing Canada's leading environmental expert, the internationally renowned David Suzuki. When I turned the topic to global overpopulation I expected to hear the same waffle that virtually all politicians and economists spout. My expectation was based on the Suzuki Foundation website and discussions with several Foundation managers: in no way whatsoever does population play a part of their campaigns or strategy. The topic is shunned, as it is by virtually all environmental organizations.

To my surprise Suzuki discussed the issue openly and frankly. 'A growing population makes almost every environmental problem worse,' he said. He was careful to distinguish between the different problems that face developed and developing nations. The footprint of a North American is many times that of someone from China or India he emphasized, so consumption is a big part of the equation. Suzuki feels Canadians and Americans need to decrease their environmental footprint by $80 \%$. That's a deep and painful cut that can't be achieved without also decreasing population growth.

The populations of Canada and the United States, with less than 2.2 births per woman, will stabilize. But immigration, which makes up two-thirds of population growth, is a problem. Suzuki feels immigration should be decreased because it increases the eco-footprint of the immigrants to North American levels. A better method, he suggests, is to decrease immigration and spend far more on foreign aid, especially for women's education. He's upset that there is not a single commit- 
tee on population in federal government and says, 'it's a disgrace that Canada [like the United States] has no national population policy.' [clearly Canadians have ignored Vallentyne (1975) - S.H.H.]

When I asked about the future, Suzuki responded, 'The world is going down the chute,' he said, 'I'm old so it doesn't matter to me. But it pisses me off that our grandchildren will be affected.' It gave me a chill that one of the world's most respected environmentalists has such a negative outlook.

For long-term survival it's vital that we move to living in a state of equilibrium. And that includes consumption and population.

A couple of months earlier, Suzuki had briefly expressed the same thought in an email responding to another questioner:

The challenge for Canada is to stop this crazy notion that we've got to keep the economy growing by adding more people. Canadians are having less than 2 children per couple so to keep the economy climbing, we bring more and more people from low consuming countries and convert them to high consumers. This is nuts (D. Suzuki, email to Peter Salonius, 21 October 2008).

I mildly challenged Suzuki to follow through on the thoughts he expressed in his interview at the University of Victoria and to Peter Salonius: 'You've done such a good job on so many other issues, maybe now's the time to 'go afterburners' on the Canadian population issue - and take the heat that most of our fellow academics and environmentalists and their timid organizations can't handle' (S.H.H., email to D. Suzuki, 17 February 2010). Certainly he must recognize that while these ideologically hidebound folks may not themselves be pushing the planet down 'the chute', their timidity and myopia is the grease that allows the 'growth über alles' political, religious and commercial establishments to accelerate the slide. Biting the bullet on this issue might also get the SuzukiWatch website (http://suzukiwatch.wordpress. com/) off his back. This website is dedicated to lambasting him for allegedly misleading Canadians into thinking that Canada's environmental problems can be dealt with merely by changes in consumption patterns, lifestyles and technology.

Addressing Canada's population problem would require nothing more than extension of principles articulated by Konrad Otto-Zimmerman, head of the International Center for Local Environmental Initiatives in Freiburg, Germany, whom Suzuki \& Dressel (2002, p. 337-339) enthusiastically paraphrase and quote:

In Germany ... the state authority cannot override decisions made at the local level. ... The protection of local autonomy is only one way in which the citizens of the city of Freiburg show their expertise in conducting democracy. ... Local, democratic power is the most fundamental and necessary requirement of sustainability. ... Otto-Zimmerman says, 'Globalists don't mind where they live, where they buy things, where those things come from. Borders, to them just cause confusion, trouble, inefficiency. They are mentally torn down. But people who care about a certain place, they have real relations with it and with each other. And what we're learning now is that we really can have the best of both; internationalist populations that can see beyond local borders, and really care about what happens in other countries, but that also take care of their own homes, their Heim.'

In the closing sentences of their book, Suzuki \& Dressel (2002, p. 355) urge that, 'we can now, thanks to electronic communications if nothing else, reach a global consensus ... [about how to build] sustainable environmental, economic and social structures.' They sound more globalist than internationalist. In his lowkey way, Jack was ahead of them.

Suzuki eventually responded to my suggestion saying, in essence, that the press of other business prevented him from taking up the challenge.

\section{JACK, GARRETT HARDIN AND THE CANADIAN POPULATION QUESTION}

Garrett Hardin was another distinguished scientist who prodded Jack to write Mouse Utopia (Vallentyne 2006, p. v). Among prominent environmentalists, a sharper contrast with David Suzuki could not be found. With reference to the demotechnic equation $C=P(1+\mathrm{D}$-index $)$, Suzuki focused almost exclusively on the D-index, while Hardin's work emphasized the $P$ factor. And while Suzuki apparently never published anything on immigration's contribution to the $P$ factor, Hardin published a great deal on that topic.

I have been unable to ascertain the nature of any personal relationship between Jack and Hardin, who died in 2003. Admiration of each other's work and philosophy would have been natural as both were outspoken internationalists, not globalists, as Konrad Otto-Zimmerman (quoted above) and others (e.g. Beck \& Kolankiewicz 2000, Hurlbert 2000, 2011b) use these terms.

Quotes from 3 of Jack's publications define the pragmatic internationalist view as to how resource use and population growth are most effectively managed:

We also view nations as ecosystems, i.e. as politically defined subdivisions of the Biosphere. ... The use of political boundaries to define ecosystems may seem 
strange to ecologists and politicians alike; nevertheless we believe it is essential to effective management of the human uses and abuses of natural resources.... [A] strong case can be made for viewing nations as ecosystems in the sense that they are functionally held together by systems of industrial production, transport, communication, agriculture, law, and politics that are inextricably linked to other (nonhuman) systems of nature. ... [O]nly governments have the resources to undertake systemic analyses of the flows of energy, materials, and information in large-scale systems. (Vallentyne \& Hamilton 1987, p 515)

With the Biosphere as context, nations need to recognize themselves for what they are: politically defined ecosystems (i.e. subdivisions of The Biosphere), responsible for managing their resources in both national and Biospheric interest. (Vallentyne 1988, p. 409)

The main stumbling block to the integrated action of nations is the sovereignty principle, which states that in the last analysis nations have the right to do whatever they want to ensure their survival. To some this calls for world government. While this could result, I think a more probable future is establishment of institutions ... working on the basis of moral suasion. ... [It is not reasonable to expect] that governments at any level can ever realistically represent Biospheric interests. (Vallentyne 1994, p 537)

Jack's views in this area were almost certainly influenced by Hardin, who wrote copiously on population issues starting in the 1950s, who was widely read by ecologists, and who strongly advocated the internationalist perspective in relation to immigration and family planning policies. Two quotes give the flavor:

Our responsibility is to keep our country from being overwhelmed by immigrants. The responsibility of each poor country is to keep the excess population from being produced. ... To realize a country's inherent richness, a government must see to it that population matches the carrying capacity of the land. ... Each country must choose the means that meshes with its culture. (Hardin 1981, p. 45)

Never globalize a problem if it can possibly be solved locally. ... We will make no progress with population problems, which are a root cause of both hunger and poverty, until we deglobalize them. ... We are not faced with a single global population problem but, rather, with about 180 [now 196] separate national population problems. ... All population controls must be applied locally; local governments are the agents best prepared to choose local means ... Means must fit local traditions. For one nation to attempt to impose its ethical principles on another is to violate national sovereignty and endanger international peace. The only legitimate demand that nations can make on one another is this: 'Don't try to solve your population problem by exporting your excess people to us.' (Hardin 1989, p. 11ff)

Hardin (1993) expands on these ideas in his classic work, Living Within Limits: Ecology, Economics and Population Taboos, where, following Betts (1988), he uses parochial and cosmopolitan as labels for the 2 worldviews. In that book's final paragraph (p. 311-312) Hardin concludes:

There is no all-powerful world government to achieve universal population control; and there is no reason to expect one to develop. Population control must be coextensive with sovereignty. The existence of many sovereignties calls for the parochial control of population. ... Let us hope that ours is one of the countries that manages to find-and accept-effective means of controlling its population.

These views of Jack and Hardin should appear eminently sensible to most readers. Unfortunately they are quite unacceptable to many globalists who claim to be pro-environment, anti-poverty, etc. but who wish responsibility for population matters to be transferred into the hands of international or supranational bodies of one sort or another. Tobias (1994, p. xxxv), for example, recommends formation of 'an international legal body that would determine interregional immigration policies based upon the calculated unburdening of biodiversity hotspots'_even as he complains (p. 390) that the USA has no population policy of its own!

Tobias (1994, p. 558) also offers this frontal attack on the internationalist viewpoint of Jack, Otto-Zimmerman, Hardin and most other serious analysts of these problems, though without mentioning any author by name:

Some have argued that it is precisely human boundaries that provide inherent management systems for nature. That by keeping immigrants out, hence forcing nations to deal with their own ecological problems, humankind can exercise better micromanagement over its ecological dilemmas. But this argument has been tested for several thousand years and it has faltered.

Such statements reflect a naïve and reckless utopianism. All that has 'faltered' is the 'argument' that abandonment of sovereignty and local control, and transfer of power and responsibility to distant bureaucracies, will solve our problems. More anarchic forms of globalism, as reflected for example in the ostrich-like attitudes of many American and Canadian environmental and scientific organizations to immigration flows and policy (e.g. Salonius 1999, Beck \& Kolankiewicz 2000, Hurlbert 2000, 2011c,d, e,f, Kolankiewicz 2011, Walker 2011), also have only negative environmental consequences.

With both his feet in the internationalist camp and his eyes wider open than most of his fellow environmental scientists, why did Jack never return with vigor to the theme of his remarks (Vallentyne 1975) at the meeting in the Fort Garry Hotel in 1974? Why did he not use his scientific standing to advocate stabilization of Canada's population? In 1974 this was 23 
million, more than twice what Schindler (2000) later guessed was the maximum population that might be responsibly sustainable over the long run given Canada's demotechnic index and its special need to 'protect cultures that depend on sparse populations and large land areas,' i.e. First Nation peoples.

The final lines in Jack's 1975 talk read as follows:

The first recommendation under the heading of Population at the November 18-22, 1973, Man \& Resources Conference [CCREM 1974] was as follows: 'Deeply concerned with the impact of growing environmental problems on the quality of both urban and rural life, and by the wasteful consumption of natural resources, we call on all governments to: (1) develop an explicit national population policy which would accommodate the growth inherent in the present population but allow for a leveling off of further growth by the year 2000.' I strongly urge that this recommendation be acted on before we find ourselves in a difficultly reversible situation. Let us not be deceived by the view out the window. (Vallentyne 1975, p. G8)

The deceptive spring greenery of Winnipeg again! Because that advice was not acted upon by Canada or almost any other country, Jack tries again $32 \mathrm{yr}$ later in the opening pages of Mouse Utopia (Vallentyne 2006, p. 2):

This book claims that the fulfillment of human shortterm desires has fueled a runaway growth cycle in which technology and population have spurred each other to ecologically unsustainable heights. ... If this suicidal behavior continues, Human Utopia, like Mouse Utopia, will self-destruct.

Jack may have declined to push more forcefully for stabilization or reduction of Canada's population and demotechnic footprint for 2 principal reasons. First, as immigration has for some decades been the primary driver of population growth in Canada (as in the USA), it would have required advocating reduced immigration into Canada in the face of powerful, environmentally blind interests favoring high immigration rates. This would have created several difficulties for Jack as discussed below.

Second, by mid-career he was developing a somewhat jaundiced view of the educability, wisdom and political courage of adults, especially those in government. Referring to Jack's displeasure over the transfer of the Fisheries Research Board of Canada into the Canadian civil service, Schindler (email to J. Burman, obituary writer for the Hamilton Spectator, 21 June 2007) candidly noted:

It was during this period that he developed his Johnny Biosphere persona. I know from personal conversations at that time that Jack was giving up on adults, set in their selfish ways, and pinned his hope on enlightening the next generation.
The newspaper, opting for euphemism over candor, simply noted that Jack 'was becoming frustrated with bureaucrats and adults' (Burman 2007).

More speculatively, Jack's dismay likely extended to adults in Canada's scientific and environmental communities. He would have known that most of these colleagues would have given him no public support if he entered the controversial arena of immigration policy.

Here in capsule form is a recent official statement on immigration by the Honourable Jason Kenney, PC, MP Minister of Citizenship, Immigration and Multiculturalism (CIC 2009):

As Minister of Citizenship, Immigration and Multiculturalism, I am pleased to present the 2009 Annual Report to Parliament on Immigration.

Canadians can be very proud of the fact that throughout our history we have maintained a tradition of openness to newcomers from around the world. We have maintained the highest relative level of immigration of any major western country, attracting nearly a quarter of a million permanent residents in 2008. In 2010, we intend to welcome between 240000 and 265000 permanent residents.

In the past five years, Canada has relied on immigration for more than two-thirds of its population growth, and within the next decade we expect that all our labour force growth will come from immigration. This presents tremendous opportunities along with certain challenges.

Those words reflect the same general immigration policies in force during much of Jack's adult life, the increased numbers of immigrants annually allowed into Canada starting in about 1990, and the desire by some to increase those numbers even further. The anti-environmental 'immigration industry' and growth über alles corporate sector run the show. Jack must have been perturbed by such very un-green, demotechnic insanity ruling Canada. Perhaps he was aware of 2 organizations, the Population Institute of Canada (founded in 1992) and Immigration Watch Canada (founded in 2003). Created by a few Vallentyne-like ecocatalysts, those organizations now may be the most effective ones in Canada in promoting the environmentally responsible agenda laid out at the 1973 Man and Resources Conference in Toronto and in Jack's 1974 talk at the Fort Garry Hotel (Vallentyne 1975). But how much better might the current situation be if, 1 or 2 decades ago, a scientist of Jack's stature had lent their name, intellect and energy to this movement? Maybe he could even have pulled the shy David Suzuki in with him!

Yet Jack's opting out of immigration policy battles was fully understandable from every viewpoint. Even a mighty 'eco-warrior' (per Burman 2007) must choose his battles carefully, and Vallentyne was 
reputedly an apt student of Sun Tzu's The Art of War (Hamilton 2011).

In the United States, every leader or organization that has had some success in preventing increased immigration into the United States has for many years been slandered as 'racist,' 'white supremacist,' 'xenophobic,' 'nativist,' 'neo-Nazi', etc. by ideologues of both the left and the right. And much of the mainline media has always been happy to report those charges uncritically. No doubt the same has been true in Canada. Would news stories reporting some organization's claim that Jack was fraternizing with 'racists' have helped or hurt his efforts to help reduce the production and use of chlorine-containing materials? Would Johnny Biosphere have been so welcome in schools if two-bit politicians were broadcasting that Johnny Biosphere was an 'anti-immigrant xenophobe in sheep's clothing'? Indeed, the government itself might have given him grief, as a Canadian government employee and admirer of Hardin, for reasons most Americans are little aware of. In a tribute to Garrett Hardin, Kolankiewicz (2003) recounts:

At least in the United States, because of our tradition of free speech, we have some assurance that ideas like Garrett's, however unpopular, can be aired and debated, if not accepted. However, even our sibling country and neighbor to the north, Canada, does not enshrine freedom of speech and in fact is willing to censor ideas for the sake of public order, social engineering, and misguided utopianism. This will eventually cost it dearly (and this pains me, as one who lived in Canada for four years and admires it in many ways). When I worked at CCN [Carrying Capacity Network], I'm sure that an envelope containing CCN literature I once sent to a member of our Board of Advisors in Canada, which never reached him, was stopped by Canadian authorities at the border as 'hate speech.' Similarly, Roy Beck has seen his own highly regarded 'Immigration by the Numbers' video - introduced by none other than Earth Day founder and former U.S. Senator Gaylord Nelson in one version - on a list of materials banned in Canada. It's only a matter of time before Garrett Hardin's books are banned or burned by Canadian authorities, if they haven't been already.

At a more personal level, almost any scientist in Canada, as in the USA, is likely to have many immigrants as close friends and colleagues; one might worry about even the most rational discussion of immigration policies giving personal offense and cooling friendships. Jack personally, of course, had little likelihood of being taken to task by his colleagues on that point. In the late 1960s he was a 'coyote' or human smuggler of legendary efficiency in bringing top scientists to Canada from the USA, Europe and Asia! Additionally, Canada's immigration policies could not usefully or appropriately be addressed in the international scientific arenas in which Jack often was operating.

Jack did more than his share in showing the way to a brighter demographic and demotechnic future for Canada and the world. A student of Sun Tzu, he was wise enough to know he could not do more of the 'heavy lifting' in the absence of better support from fellow scientists and scientific societies - or perhaps even with it. He would hope that some of those seeds he spread around as Johnny Biosphere are now saplings or sturdy trees getting off their own first seed sets - and being civilly 'obnoxious' on population issues.

Acknowledgements. For providing information and/or commenting on this manuscript, I thank the following individuals: Gregg Brunskill, Ana Guimares, Andrew Hamilton, Brishen Hoff, Leon Kolankiewicz, Kerry McDonald, Dan Murray, David Pimentel, Richard Schneider, Gerald Shaw, John Shearer, David Suzuki, Wayne Taylor and Peter Vallentyne.

\section{LITERATURE CITED}

Beck R, Kolankiewicz L (2000) The environmental movement's retreat from advocating U.S. population stabilization (1970-1998): a first draft of history. J Policy Hist 12: $123-156$

Betts K (1988) Ideology and immigration: Australia 1976 to 1982. Melbourne University Press, Melbourne

> Blanchfield PJ, Paterson MJ, Shearer JA, Schindler DW (2009) Johnson and Vallentyne's legacy: 40 years of aquatic research at the Experimental Lakes Area. Can J Fish Aquat Sci 66:1831-1836

Bryson RA, Ross JE (1972) On the nature of environmental concern. University of Wisconsin Institute for Environmental Studies Working Paper 3, Madison, WI, p 1-24

Burman J (2007) Johnny Biosphere: early eco-warrior. Hamilton Spectator (22 June 2007), Hamilton, Ontario. Available at www.thespec.com/news/canada/article/ 219923--johnny-biosphere-early-eco-warrior

Calhoun JB (1973) Death squared: the explosive growth and demise of a mouse population. Proc R Soc Med 66:80-88

CCREM (Canadian Council of Resource and Environment Ministers) (1974) Proceedings of the Man and Resources Conference, November 18-22, 1973, Toronto, Ontario. CCREM, Toronto, Ontario

> Chertow MR (2000) The IPAT equation and its variants. J Industr Ecol 4:13-29

CIA (Central Intelligence Agency) (2010) Country comparison: life expectancy at birth. The World Factbook, US CIA, Langley, VA. Available at: https://www.cia. gov/library/publications/the-world-factbook/rankorder/ 2102rank.html (accessed on 5 March 2010)

CIC (Citizenship and Immigration Canada) (2009) Annual report to Parliament on immigration, 2009. CIC, Ministry of Public Works and Government Services Canada, Ottawa, Ontario. Available at: www.cic.gc.ca/english/ resources/publications/annual-report2009/index.asp (accessed on 14 April 2011) 
Commoner B (1971) The closing circle: nature, man and technology. Knopf, New York, NY

Commoner B (1972) A bulletin dialogue on 'The closing cir-

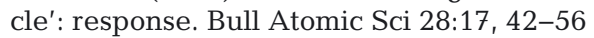

> Daily GC, Ehrlich AH, Ehrlich PR (1994) Optimum population size. Popul Environ 15:469-475

Desvaux M (2007) Current population is three times the sustainable level. Balanced View (World Population Balance Newsletters), August 2007, p 1,8

Dietz T, Rosa EA (1994) Rethinking the environmental impacts of population, affluence and technology. Hum Ecol Rev 1:277-300

Ehrlich PR, Holdren JP (1971) Impact of population growth. Science 171:1212-1217

Ehrlich P, Holdren J (1972) A bulletin dialogue on 'The closing circle': critique. Bull Atomic Sci 28:16, 18-27

Ehrlich PR, Ehrlich AH, Daily GC (1993) Food security, population and the environment. Popul Dev Rev 19:1-32

Ferguson ARB (1998) World carrying capacity: an interim report. Optimum Population Trust, Manchester. Available at: www.members.aol.com/optjournal/cc3.doc (accessed on 7 December)

> Ferguson ARB (2001) Population and the demise of cheap energy. Politics Life Sci 20:217-226

Hamilton AL (2011) John R. (Jack) Vallentyne: enduring issues in leadership. Aquat Ecosyst Health Manag 14: 138-144

Hanauer, MG (1998) Overpopulation and overconsumption: Where should we focus? NPG Forum, March 1998. Negative Population Growth, Washington DC

Hardin G (1981) The toughlove solution. Newsweek, 26 October 1981, p 45

Hardin G (1989) There is no global population problem. Humanist 49(4):11-13, 32

Hardin G (1993) Living within limits: ecology, economics, and population taboos. Oxford University Press, New York, NY

Hoefer M, Rytina N, Baker BC (2010) Estimates of the unauthorized immigrant population residing in the United States: January 2009. Office of Immigration Statistics, US Department of Homeland Security, Washington, DC

Holdren JP (1973) Population and the American predicament: the case against complacency. Daedalus 102: 31-43

Holdren JP (2008) Science and technology for sustainable well-being. Science 319:424-434

Holdren JP (2011) Policy for science, technology and innovation in the Obama Administration: a mid-course update. Plenary lecture, 2011 Annual Meeting of the AAAS, Washington, DC, 18 February 2011. PowerPoint presentation available at: www.aaas.org/meetings/2011/ program/plenaries/media/0218holdren_presentation.pdf

Hurlbert SH (2000) The globalist copout. Soc Contract 10: 193-194

Hurlbert SH (2011a) Serendipitous intersections with Jack Vallentyne. Aquat Ecosyst Health Manag 14:165-169

Hurlbert SH (2011b) Immigration control and biodiversity in North America. Soc Contract 21(3):21-22

Hurlbert SH (2011c) Wives of the Bishop of Worcester: the ESA and global copoutism. Soc Contract 21(3):7-13

Hurlbert SH (2011d) The North American Lake Management Society: axing truth, threatening lawsuits. Soc Contract 21(3):37-41

Hurlbert SH (2011e) Pacific salmon, immigration and censors: unreliability of the cowed technocrat. Soc Contract
21(3):42-46

Hurlbert SH (2011f) Is the AAAS oblivious to U.S. overpopulation and its consequences? Or is it just another censor? Soc Contract 22(1):67-71

Kolankiewicz L (2003) Tribute to Garrett Hardin. Garrett Hardin Society, Santa Barbara, CA. Available at: www.garretthardinsociety.org/tributes/tr_kolankiewicz_ 2003oct.html (accessed on 7 December 2011)

Kolankiewicz L (2011) Immigration, population growth, and environmentalist hypocrisy on the border fence. Soc Contract 21(3):25-26

Mann D (2009) Essay on a sustainable economy. NPG Forum Ser 2009 Negative Population Growth, Alexandria, VA

Mata FJ, Onisto LJ, Vallentyne JR (2012) Consumption: the other side of population for development. Ethics Sci Environ Polit 12:15-20

Meyerson FAB (2004) Immigration, population policy, and the Sierra Club. Population and Environment 26:61-69

Munawar M (ed) (2011) Memorial issue for John R. Vallentyne and Richard A. Vollenweider. Aquat Ecosyst Health Manag 14:115-228

PCAST (President's Council of Advisors on Science and Technology) (2011) Sustaining environmental capital: protecting society and the economy. PCAST, Washington, DC

Pimentel D, Pimentel M (1996) Food, energy and society, revised edn. University Press of Colorado, Niwot, CO

Pimentel D, Harman R, Pacenza M, Pecarsky J, Pimentel M (1994) Natural resources and an optimum human population. Popul Environ 15:347-369

Pimentel D, Bailey O, Kim P, Mullaney E and others (1999) Will limits of the earth's resources control human numbers? Environ Dev Sustain 1:19-39

Pimentel D, Whitecraft M, Scott ZR, Zhao L and others (2010) Will limited land, water and energy control human population numbers in the future? Hum Ecol 38:599-611

Planas D (2008) John R. Vallentyne, in memoriam. Limnetica $27: \mathrm{i}-\mathrm{ii}$

Rees WE (1992) Ecological footprints and appropriated carrying capacity: what urban economics leaves out. Environ Urban 4:121-130

Rees WE, Wackernagel M (1994) Ecological footprints and appropriated carrying capacity: measuring the natural capital requirements of the human economy. In: Jansson A, Hammer M, Folke C, Costanza R (eds) Investing in natural capital. Island Press, Washington, DC, p 363-390

Ryerson WN (2012) Vallentyne was right: achieving sustainability requires accounting for all relevant factors. Ethics Sci Environ Polit 12:5-13

- Salonius PO (1999) Population growth in the United States and Canada: a role for scientists. Conserv Biol 13: 1518-1519

Schindler DW (2000) The ecological rights of humans. In: Bhatia GS, O'Neill JS, Gall GL, Bendin PD (eds) Peace, justice and freedom: human rights challenges for the new millenium. University of Alberta Press, Edmonton, p 119-126

Schindler DW (2007) Obituary: John R. Vallentyne. SIL News 51:1-2 (Int Soc Limnol)

Schindler DW, Vallentyne JR (2008) The algal bowl: overfertilization of the world's freshwaters and estuaries, 2nd edn. University of Alberta Press, Edmonton

Smail JK (1997) Population growth seems to affect everything but is seldom held responsible for anything. Politics Life Sci 16:231-236 
Smail JK (2002) Confronting a surfeit of people: reducing global human numbers to sustainable levels. Environ Dev Sustain 4:21-50

Smail JK (2003) Remembering Malthus II: establishing sustainable population optimums. Am J Phys Anthropol 122: 287-294

Suro R (2005) Attitudes toward immigrants and immigration policy: surveys among Latinos in the U.S. and in Mexico. Pew Hispanic Center, Washington, DC

Suzuki D, Dressel H (2002) Good news for a change: hope for a troubled planet. Oregon State University Press, Corvallis OR

Tammemagi H (2008) Suzuki on population. Runaway human population-a blog. Available at: http://runaway-human-population.blogspot.com/2008/12/suzukion-population.html (accessed on 7 December 2011)

Tobias M (1994) World War III: population and the biosphere at the end of the millenium. Bear, Santa Fe NM

USCB (US Census Bureau) (2009) 2008 American community survey 1-year estimates: place of birth for the foreign-born population. USCB, Washington, DC. Available at: http://factfinder.census.gov/servlet/MetadataBrowser Servlet?type=dataset\&id=ACS_2008_1YR_G00_\&_lang= en (accessed on 14 April 2011)

Vallentyne JR (1972a) Freshwater supplies and pollution: effects of the demophoric explosion on water and man. In: Polunin N (ed) The environmental future. Macmillan, London, p 181-211

Vallentyne JR (1972b) Demophora (letter to the editor). Environment 14(6):47-48

Vallentyne JR (1975) Responsible statehood: the need for a population policy. In: Richmond KB, Keleher JJ (eds) Manitoba 2000: population size and distribution. Manitoba Environmental Council, Winnipeg, Manitoba, p G1-G8

Vallentyne JR (1978) Today is yesterday's tomorrow. Verh Int Verein Limnol 20:1-12

Vallentyne JR (1980) Twenty-first congress of the Interna-

Editorial responsibility: Daryl Macer,

Bangkok, Thailand tional Association of Limnology (SIL), held at the International Conference Center, Kyoto, Japan, during 24-31 August 1980. Environ Conserv 7:336

Vallentyne JR (1982) A new approach to membership dues schedules for use by international organizations. Biol Int 5:10-12

Vallentyne JR (1988) First direction, then velocity. Ambio $17: 409$

Vallentyne JR (1994) Not politics, but ecology. In: Margalef $\mathrm{R}$ (ed) Limnology now: a paradigm of planetary problems. Elsevier Science, Amsterdam, p 529-576

Vallentyne JR (2006) Tragedy in mouse utopia: an ecological commentary on human utopia. Trafford Publishing, Victoria

Vallentyne JR, Hamilton AL (1987) Managing human uses and abuses of aquatic resources in the Canadian ecosystem. In: Healey MC, Wallace RR (eds) Canadian aquatic resources. Can Bull Fish Aquat Sci, Department of Fisheries and Oceans, Ottawa, p 513-533

> Vallentyne JR, Tracy HL (1972) New term introduced at First Conference on Environmental Future. Biol Conserv 4: 371-372 (reprinted in Bull At Sci 29:24, 1973)

Wackernagel M, Rees WE (1996) Our ecological footprint: reducing human impact on the earth. New Society Publishers, Gabriola Island

Wackernagel M, Onisto L, Bello P, Callejas Linares A and others (1999) Natural capital accounting with the ecological footprint concept. Ecol Econ 29:375-390

Waggoner PE, Ausubel JH (2002) A framework for sustainability science: a renovated IPAT identity. Proc Natl Acad Sci USA 99:7860-7865

Walker B (2011) The Sierra Club's profitable descent into leftism. Soc Contract 21(3):47-49

Wetzel RG (2001) Limnology: lake and river ecosystems, 3rd edn. Academic Press, New York, NY

York R, Rosa EA, Dietz T (2003) STIRPAT, IPAT and ImPACT; analytic tools for unpacking the driving forces of environmental impacts. Ecol Econ 46:351-365

Submitted: April 1, 2011; Accepted: October 6, 2011

Proofs received from author(s): December 9, 2011 